\title{
ANALISIS DAMPAK PANDEMI COVID 19 TERHADAP PEREKONOMIAN LOKAL DARI SUDUT PANDANG JENIS PEKERJAAN DAN PENDAPATAN TERHADAP TINGKAT DAYA BELI MASYARAKAT DI JAWA TENGAH
}

\author{
Santosa \\ Widyaiswara Ahli Madya BPSDMD Provinsi Jawa Tengah \\ sekarlangits@yahoo.co.id
}

\begin{abstract}
Before COVID-19 broke out in Indonesia, Indonesia's economic growth in the fourth quarter of 2019 was below 5 percent, to be precise at 4.97 percent. This condition clearly makes Indonesia's economic growth in 2019 lower than the target set by the government (5.3 percent) or to be precise only at 5.02 percent. The research method used in this research is a descriptive survey with a cross-sectional research design through a survey questionnaire taken from a google form with the link http://bit.ly/KuesDpkEkoSants which is distributed via Whatsapp and Facebook to the network for one week. The sample used in this study is probability sampling. The population in this study are all people with various types of work who are in Central Java and who can access google forms. The conclusion is that as a whole it can be interpreted that all types of work in various sectors have felt or were affected by the COVID-19 pandemic very significantly from the research results, it was found that $t$ count $(6,548)>t$ table $(1,980)$ and sig value $0.005<0.005$, that the income of respondents before the COVID-19 pandemic -19 and after the Pandemic had a profound impact on respondents' income. and also the purchasing power of respondents 'personal and family needs before the COVID19 pandemic had a very significant impact on the purchasing power of respondents' personal and family needs during the COVID-19 pandemic.
\end{abstract}

Keywords $\quad$ : COVID-19, Local Economy, Type Of Work, Income, Level Purchasing Power.

\begin{abstract}
ABSTRAK
Sebelum COVID-19 merebak di Indonesia, pertumbuhan ekonomi Indonesia di kuartal keempat 2019 telah berada di bawah 5 persen, tepatnya berada di angka 4,97 persen . Kondisi tersebut jelas membuat pertumbuhan ekonomi Indonesia di tahun 2019 lebih rendah dari target yang ditetapkan pemerintah (5,3 persen) atau tepatnya hanya berada di angka 5,02 persen. Metode penelitian yang digunakan dalam penelitian ini adalah deskriptif survei dengan desain penelitian cross sectional study melalui kuesioner Survei yang dibagikan menggunakan google form dengan link http://bit.ly/KuesDpkEkoSants yang di sebarkan melalui Whatsapp dan Facebook ke jejaring selama satu minggu. Sampel yang digunakan dalam penelitian ini adalah probability sampling. Populasi dalam penelitian ini adalah seluruh masyarakat dengan berbagai jenis sektor pekerjaan yang berada di Jawa Tengah dan yang dapat mengakses google form. Kesimpulan bahwa secara menyeluruh dapat diartikan seluruh jenis pekerjaan diberbagai sektor merasakan atau terdampak Pandemi COVID-19 dengan sangat signifikan dari hasil penelitian didapatkan bahwa $t_{\text {hitung }}(6,548)>t_{\text {tabel }}$ $(1,980)$ dan nilai sig 0,005<0,005, bahwa pendapatan responden sebelum Pandemi COVID-19 dan sesudah Pandemi sangat berdampak secara signifikan terhadap pendapatan responden. dan juga Daya Beli Kebutuhan Pribadi dan Keluarga responden sebelum Pandemi COVID-19 sangat berdampak secara signifikan terhadap Daya Beli Kebutuhan Pribadi dan Keluarga responden pada saat Pandemi COVID-19.
\end{abstract}

Kata Kunci : COVID-19, Perekonomian Lokal, Jenis Pekerjaaan,Pendapatan, Tingkat Daya Beli. 


\section{PENDAHULUAN}

Pertumbuhan ekonomi sebagai sebuah proses peningkatan output dari waktu ke waktu menjadi indikator penting untuk mengukur keberhasilan pembangunan suatu negara. Oleh karena itu identifikasi berbagai macam faktor yang mempengaruhi termasuk peran pemerintah menjadi menarik untuk dikaji lebih dalam. Menurut teori dasar pertumbuhan ekonomi Nelklasik dari Solow dan Swan (1956) tidak terdapat pengaruh peran pemerintah terhadap pertumbuhan baik dalam bentuk pengeluaran maupun pajak. (Kneller,Richard dkk,1999).

Pertumbuhan ekonomi hanya dipengaruhi oleh stok kapital, tenaga kerja dan teknologi yang bersifat eksogen. Pemerintah dapat mempengaruhi pertumbuhan populasi yang akan mempengaruhi ketersediaan tenaga kerja namun tidak berdampak pada pertumbuhan ekonomi. Teori pertumbuhan endogen (endogeneo us growth theory) menjelaskan bahwa investasi pada modal fisik dan modal manusia berperan dalam menentukan pertumbuhan ekonomi jangka panjang. Kontribusi pemerintah terhadap pertumbuhan ekonomi dapat dijelaskan melalui pengaruhnya dalam melakukan perubahan komsumsi atau pengeluaran untuk investasi publik dan penerimaan dari pajak

Di Indonesia sektor pemerintah memiliki peranan besar dalam sejarah perekonomian. Peran tersebut dituangkan dalam bentuk pelaksanaan kebijakan fiskal untuk mencapai tujuan utama pembangunan berupa pertumbuhan ekonomi yang tinggi, mengurangi pengangguran dan mengendalikan inflasi. Kebijakan fiskal yang dijalankan pemerintah Indonesia memiliki dua instrumen utama yaitu perpajakan dan pengeluaran.
Pada awal tahun 2020, dunia dihebohkan dengan adanya wabah virus corona yang berasal dari China. Virus yang menimbulkan korban ribuan jiwa penduduk China. Akibat lainnya, banyak perusahaan kecil, menengah maupun besar yang akhirnya terpaksa menutup usahanya untuk sementara. Tidak hanya perusahaan saja yang tutup, ribuan tempat usaha makanan/ minuman juga terpaksa tutup karena instruksi lockdown dari pemerintah setempat. Perekonomian China pun menjadi terguncang di awal tahun 2020 ini, karena selama ini perekonomian China didukung dari sektor usaha kecil dan menengah. Ada sekitar 30 juta usaha kecil dan menengah menyumbang lebih dari 60\% dari Produk Domestik Bruto (PDB) China. Selain itu, bursa saham Shanghai juga sempat menurun mencapai $9 \%$, yang merupakan yang terparah sejak bulan Agustus 2015. (Fajriyah, 2020).

Organisasi Kesehatan Dunia (World Health Organization) telah menetapkan status gawat darurat global untuk wabah virus corona. Dunia menjadi waspada akan wabah virus ini. Tidak hanya waspada terhadap penyebaran penyakitnya saja akan tetapi juga waspada terhadap dampak yang mungkin terjadi terhadap perekonomian dunia. Menurut Direktur Pelaksana IMF, Kristalina Georgieva, dengan adanya wabah virus corona, diperkirakan dalam jangka pendek akan terjadi perlambatan ekonomi global. (Tobing, 2020) Menurut Menteri Koordinator Bidang Perekonomian, Airlangga Hartarto, laju pertumbuhan ekonomi Indonesia dapat dipengaruhi oleh pertumbuhan ekonomi China. Jika ekonomi China mengalami pelambatan sebesar 1-2\%, maka akan berdampak pada menurunnya ekonomi Indonesia sebesar 0,1-0,3\% terhadap ekonomi Indonesia. (Fajriyah,2020

Kasus pertama COVID-19 yang dikonfirmasi oleh pemerintah Indonesia 
baru diumumkan per tanggal 2 Maret 2020, yaitu berjumlah dua orang. Kurang lebih tiga minggu setelahnya, per tanggal 20 Maret 2020, jumlah pasien positif COVID-19 melonjak signifikan menjadi 369 orang. Kondisi ini memprihatinkan dan berdampak luas, mulai dari sosial hingga ekonomi. Dampak ekonomi yang diakibatkan oleh peningkatan penyebaran COVID-19 bisa dirasakan, mulai dari fenomena panic buying, terjun bebasnya indeks harga saham, terdepresiasinya nilai tukar Rupiah terhadap Dolar Amerika Serikat (USD), lesunya kegiatan industri pengolahan (manufaktur), dan pada akhirnya berimbas pada perlambatan pertumbuhan ekonomi.

Dari sisi konsumsi, pola konsumsi masyarakat akibat penyebaran COVID-19 secara otomatis akan berubah. Masyarakat akan cenderung untuk tidak melakukan kegiatan perjalanan atau pariwisata dan lebih cenderung meningkatkan konsumsi pada barang-barang kebutuhan pokok yang dianggap penting sebagai antisipasi terjadinya pembatasan pergerakan manusia. Secara keseluruhan, tingkat konsumsi akan cenderung turun karena harga yang terdistorsi akibat mahalnya biaya transportasi dan logistik barang. Sementara itu, dari sisi produksi, beberapa sektor utama di Indonesia juga akan terdampak akibat penyebaran COVID-19, khususnya industri pengolahan (manufaktur).

Sebelum pandemi COVID-19 muncul, data Dana Moneter Internasional (International Monetary Fund (IMF)) memperlihatkan pertumbuhan ekonomi dunia di tahun 2019 sudah turun cukup signifikan di level 3 persen, dari sebesar 3,6 persen di tahun 2018. Di tahun 2020, IMF memproyeksi pertumbuhan ekonomi dunia akan kembali menunjukkan tren positif, yaitu sebesar 3,4 persen. Namun, tampaknya perlu ada revisi dari angka tersebut, khususnya setelah WHO mengumumkan COVID-19 sebagai pandemi. Sementara itu, dari sudut pandang dalam negeri, pertanyaan mengerucut pada seberapa serius pemerintah Indonesia dalam menjalankan reformasi struktural, khususnya terkait peningkatan daya saing, produktivitas, reindustrialisasi, peningkatan akses pembiayaan, dan peningkatan kapasitas ekonomi digital. Selain itu, reformasi birokrasi juga perlu menjadi prioritas bagi perbaikan kinerja ekonomi di dalam negeri. Implementasi kebijakan fiskal dan moneter untuk menyokong pertumbuhan ekonomi juga sangat krusial dalam menjaga sektor konsumsi, investasi, pengeluaran pemerintah, dan sektor perdagangan. Lalu bagaimana dengan kinerja pertumbuhan ekonomi Indonesia di tahun 2020? Sebelum COVID19 merebak di Indonesia, pertumbuhan ekonomi Indonesia di kuartal keempat 2019 telah berada di bawah 5 persen, tepatnya berada di angka 4,97 persen. Kondisi tersebut jelas membuat pertumbuhan ekonomi Indonesia di tahun 2019 lebih rendah dari target yang ditetapkan pemerintah $(5,3$ persen) atau tepatnya hanya berada di angka 5,02 persen. Bahkan angka tersebut lebih rendah dibandingkan dengan pertumbuhan ekonomi tahun sebelumnya (2018), yaitu sebesar 5,17 persen. (Yose,Fajar, 2020)

Menteri Keuangan Sri Mulyani Indrawati memperkirakan daya beli masyarakat atau tingkat konsumsi rumah tangga akan merosot tajam pada kuartal II2020, atau lebih lemah dibandingkan dengan realisasi daya beli pada kuartal I2020. BPS mencatat tingkat konsumsi rumah tangga merosot ke level $2,84 \%$ di kuartal I-2020 jika dibandingkan pada kuartal IV-2020 yang sebesar 5,02\%. "Kuartal II kita harus antisipasi lebih dalam lagi jatuhnya," dikutip dari statement Sri Mulyani saat raker dengan 
Komisi XI DPR via virtual, Jakarta, Rabu (6/5/2020). (Kusuma ,2020)

Potensi pelemahan daya beli pada kuartal II-2020, kata Sri Mulyani dikarenakan kebijakan pembatasan sosial berskala besar (PSBB) semakin luas dan tidak seperti pada kuartal sebelumnya yang hanya berlaku di Jabodetabek. Menurut menteri keuangan, PSBB yang berlaku di Jabodetabek saja sudah membuat daya beli masyarakat merosot tajam. Pada tingkat konsumsi rumah tangga terhadap pertumbuhan ekonomi sekitar 9.000 triliun rupiah atau 56\%, di mana sekitar 5.000 triliun rupiah berasal dari Pulau Jawa. Karena orang kalau di rumah cuma makan saja, tidak keluar transport. Pada tahun lalu konsumsi itu 9.000 triliun rupiah lebih, Pulau Jawa 55\% lebih dari 5.000 triliun rupiah, sekarang kalau 5.000 triliun rupiah di rumah ya tidak akan sampai, memang dampaknya sangat beratt dalam kuartal II. (Kusuma,2020)

Sebelumnya, Kementerian Keuangan menyatakan kebijakan pembatasan sosial berskala besar (PSBB) menjadi penyebab daya beli masyarakat alias tingkat konsumsi rumah tangga lesu. Badan Pusat Statistik (BPS) mencatat daya beli masyarakat hanya 2,84\% di kuartal I-2020. Angka tersebut turun drastis dibandingkan dengan kuartal I-2019 yang sebesar 5,02\%. Pada komponen konsumsi rumah tangga masih ada beberapa yang mengalami peningkatan, seperti konsumsi kesehatan, pendidikan, perumahan, serta perlengkapan rumah tangga. Namun itu semua tidak mampu mengimbangi penurunan konsumsi pakaian, bahan pokok, kebutuhan primer lainnya, jasa perawatan, serta transportasi dan komunikasi. Bahwa pelaksanaan pembatasan aktivitas, masyarakat mengurangi konsumsi barang-barang nonpokok. Sinyal pelemahan konsumsi ini juga terlihat pada menurunnya indeks keyakinan konsumen dan penjualan eceran pada Maret 2020 sebesar $-5,4 \%$. (Kusuma,2020)

Pada sisi industri di Indonesia. Per 7 April 2020, Kementerian Ketenagakerjaan (Kemenaker) mencatat sudah ada 1,4 juta lebih pekerja di seluruh Indonesia yang terkena dampak langsung wabah covid-19 atau corona. ${ }^{11}$ Terdapat 41.876 perusahaan sektor formal yang merumahkan atau mem-PHK tenaga kerjanya sebanyak 1.052.216 orang dan terdapat 36.298 perusahaan sektor informal yang merumahkan atau memPHK tenaga kerjanya sebanyak 374.851 orang. Daerah paling banyak adalah DKI Jakarta dengan jumlah 202 ribu tenaga kerja per 4 April 2020. Sektor yang paling banyak merumahkan/ PHK karyawannya adalah sektor pariwisata, tekstil, dan garmen. Hingga 10 April 2020, Perhimpunan Hotel dan Restoran Indonesia (PHRI) melaporkan sudah ada 1.542 Hotel yang tutup di 31 Provinsi di Indonesia, 90\% Hotel di Bali juga sudah merumahkan karyawannya. Efek negatif Covid-19 terhadap berbagai sektor sungguhlah sangat berat. ( Rina,2020)

Berdasarkan uraian latar belakang tersebut diatas, peneliti tertarik untuk mendapatkan gambaran secara nyata sejauh mana dampak Pandemi COVID-19 terhadap masyarakat Jawa Tengah dengan menganalisis pada sektor jenis pekerjaan dan Pendapatan terhadap tingkat daya beli dengan judul Penelitian Analisis Dampak Pandemi COVID-19 terhadap Perekonomian Lokal dari Sudut Pandang Jenis pekerjaan dan Pendapatan Terhadap Tingkat Daya Beli Masyarakat di Jawa Tengah.

\section{METODE}

Metode penelitian yang digunakan dalam penelitian ini adalah deskriptif survei dengan desain penelitian cross sectional study melalui kuesioner Survei 
yang dibagikan menggunakan google form dengan link http://bit.ly/KuesDpkEkoSants yang di sebarkan melalui Whatsapp dan Facebook ke jejaring yang ada selama satu minggu. Pengambilan sampel menggunakan metode probability sampling. Sampel dalam penelitian ini adalah total sampel responden yang telah mengisi kuesioner yang dibagikan menggunakan google form sejumlah 119 responden.
Instrumen penelitian yang digunakan dalam penelitian ini adalah Kuisener Survey yang dibuat oleh peneliti sesuai dengan kebutuhan untuk mengetahui gambaran Dampak Pandemi COVID-19 terhadap Perekonomian Lokal dari Sudut Pandang Jenis pekerjaan dan Tingkat Daya Beli masyarakat di Jawa Tengah. Penelitian ini dilakukan di Pati Jawa Tengah.

\section{HASIL}

\section{Analisa Univariat}

Karakteristik Jenis Pekerjaan

Tabel.1. Distribusi Frekuensi Jenis Pekerjaan Responden

\begin{tabular}{|c|c|c|c|}
\hline No & Jenis Pekerjaan & Frekuensi & ProsenTase \\
\hline 1 & $\begin{array}{l}\text { Pekerja Sektor Pemerintah (ASN/ TNI/ Polri } \\
\text { /Guru/Kesehatan/ Pejabat Politik dll) }\end{array}$ & 60 & $50.4 \%$ \\
\hline 2 & Pekerja Sektor Perdagangan & 5 & $4.2 \%$ \\
\hline 3 & Pekerja Sektor Transportasi & 1 & $0,8 \%$ \\
\hline 4 & Pekerja Sektor Pertanian & 1 & $0,8 \%$ \\
\hline 5 & Pekerja Sektor UMKM & 12 & $10.1 \%$ \\
\hline 6 & Pekerja Sektor Perhotelan & 1 & $0,8 \%$ \\
\hline 7 & Pekerja Sektor Administrasi Non ASN & 16 & $13.4 \%$ \\
\hline 8 & Pekerja Sektor Kesehatan Non ASN & 10 & $8.4 \%$ \\
\hline 9 & $\begin{array}{l}\text { Pekerja Sektor Jasa lainnya ( mis; Programer, } \\
\text { Service, Sales Promotion, Broker,WO,EO } \\
\text {,Agent lisingdll) }\end{array}$ & 1 & $0.8 \%$ \\
\hline 10 & $\begin{array}{l}\text { Pekerja Sektor Industri bahan baku ke bahan } \\
\text { jadi }\end{array}$ & 2 & $1.7 \%$ \\
\hline 11 & Pekerja Sektor Pariwisata & 1 & $0,8 \%$ \\
\hline 12 & $\begin{array}{l}\text { Pekerja Sektor Hiburan atau Pelaku Seni dan } \\
\text { Hiburan }\end{array}$ & 5 & $4.2 \%$ \\
\hline 13 & Pekerja Sektor Pendidikan Non ASN & 1 & $0,8 \%$ \\
\hline 14 & $\begin{array}{l}\text { Pekerja sektor Konstruksi atau pelaksana proyek } \\
\text { bangunan }\end{array}$ & 3 & $2.5 \%$ \\
\hline \multirow[t]{2}{*}{15} & Pekerja sektor Perbankkan atau BUMN & 60 & $50.4 \%$ \\
\hline & TOTAL & 119 & $100 \%$ \\
\hline
\end{tabular}

Sumber: Data 2020

Berdasarkan Tabel. 1 menyatakan Jenis Pekerjaan Responden terbanyak adalah Pekerjaan sektor pemerintah (ASN/TNI/Polri/Guru/Kesehatan/Pejabat Politik dll). 
Karakteristik Pendapatan Individu Perbualan

Tabel.2. Distribusi Frekuensi berdasar Karakteristik Pendapatan Individu Perbulan sebelum dan pada saat pandermi COVID-19

\begin{tabular}{|c|c|c|c|c|}
\hline \multirow{3}{*}{$\begin{array}{l}\text { Total Pendapatan } \\
\text { Individu Per Bulan }\end{array}$} & \multicolumn{4}{|c|}{ Pendapatan } \\
\hline & \multicolumn{2}{|c|}{$\begin{array}{l}\text { Sebelum Pandemi } \\
\text { Covid-19 }\end{array}$} & \multicolumn{2}{|c|}{$\begin{array}{l}\text { Pada Saat Pandemi } \\
\text { Covid-19 }\end{array}$} \\
\hline & Frekuensi & Prosentase & Frekuensi & Prosentase \\
\hline 1 Juta S.D 5 Juta & 65 & $54.6 \%$ & 88 & $73.9 \%$ \\
\hline 6 Juta S.D 10 Juta & 40 & $33.6 \%$ & 23 & $19.3 \%$ \\
\hline 11 Juta S.D 20 Juta & 10 & $8.4 \%$ & 7 & $5.9 \%$ \\
\hline 21 Juta S.D 50 Juta & 2 & $1.7 \%$ & 1 & $0.8 \%$ \\
\hline 50 Juta Keatas & 2 & $1.7 \%$ & 0 & 0 \\
\hline Total & 119 & 100.0 & 119 & 100.0 \\
\hline
\end{tabular}

Sumber: Data 2020

Berdasarkan Tabel.2 menyatakan bahwa pendapatan individu perbulan sebelum Pandemi COVID19 jumlah terbanyak adalah pendapatan 1 juta s.d 5 juta sejumlah
$65(54,6 \%)$ responden. Sedangkan pendapatan individu pada saat Pandemi COVID-19 jumlah terbanyak adalah pendapatan 1 juta s.d 5 juta sejumlah $88(73,9 \%)$ responden.

\section{Karakteristik Kategori Tingkat Daya Beli Kebutuhan Individu dan Keluarga.}

Tabel.3. Distribusi Frekuensi berdasar Karakteristik Kategori Tigkat Daya Beli Kebutuhan Individu dan Keluarga sebelum dan pada saat pandermi COVID-19

\begin{tabular}{|c|c|c|c|c|}
\hline \multirow{3}{*}{$\begin{array}{c}\text { Kategori Tingkat } \\
\text { Daya Beli } \\
\text { Masyarakat }\end{array}$} & \multicolumn{4}{|c|}{ Daya Beli Kebutuhan Individu \& Keluarga } \\
\hline & \multicolumn{2}{|c|}{$\begin{array}{l}\text { Sebelum Pandemi } \\
\text { Covid-19 }\end{array}$} & \multicolumn{2}{|c|}{$\begin{array}{l}\text { Pada Saat Pandemi } \\
\text { Covid-19 }\end{array}$} \\
\hline & Frekuensi & Prosentase & Frekuensi & Prosentase \\
\hline Rendah & 10 & $8.4 \%$ & 24 & $20.2 \%$ \\
\hline Sedang & 59 & $49.6 \%$ & 64 & $53.8 \%$ \\
\hline Tinggi & 50 & $42.0 \%$ & 31 & $26.1 \%$ \\
\hline Total & 119 & 100.0 & 119 & 100.0 \\
\hline
\end{tabular}

\section{Berdasarkan}

menyatakan bahwa Tingkat D Kebutuhan Individu dan Keluarga sebelum Pandemi COVID-19 terbanyak dengan kategori tingkat daya beli sedang sejumlah $59(49,6 \%)$ responden. Sedangkan Tingkat Daya Beli Kebutuhan Individu dan Keluarga pada saat Pandemi COVID-19 terbanyak dengan kategori tingkat daya beli sedang sejumlah $64(53,8 \%)$ responden. 


\section{Analisis Bivariat}

Pekerjaan Responden terhadap Dampak Pandemi COVID-19.

Tabel.9 Analsis Corelation Jenis Pekerjaan terhadap Dampak Pandemi COVID-19.

\begin{tabular}{lccc}
\multicolumn{4}{c}{ Paired Samples Correlations } \\
\hline & $\mathrm{N}$ & Corelation & Siq. \\
\hline $\begin{array}{l}\text { Apakah Pekerjaan saudara saat ini \& } \\
\text { TerDampak Pandemi }\end{array}$ & 119 & -.001 & .988 \\
\hline
\end{tabular}

Sumber: Data SPPS 2020

Berdasarkan pada Tabel.9 Jenis Pekerjaan Responden terhadap Pandemi COVID-19 didapatkan nila $\mathrm{r}$ - 0,001 dan Siq 0,988 > 0,005 dengan N 119 dari hasil

Tabel.10 Analsis Uji t Jenis Pekerjaan Responden terhadap Dampak COVID-19.

Paired Samples Test

\begin{tabular}{|c|c|c|c|c|c|c|c|c|}
\hline & \multicolumn{5}{|c|}{ Paired Differences } & \multirow{3}{*}{$\mathrm{t}$} & \multirow{3}{*}{ df } & \multirow{3}{*}{$\begin{array}{l}\text { Sig. } \\
(2- \\
\text { tailed }\end{array}$} \\
\hline & \multirow[t]{2}{*}{ Mean } & \multirow[t]{2}{*}{$\begin{array}{c}\text { Std. } \\
\text { Deviati } \\
\text { on }\end{array}$} & \multirow[t]{2}{*}{$\begin{array}{l}\text { Std. } \\
\text { Error } \\
\text { Mean }\end{array}$} & \multicolumn{2}{|c|}{$\begin{array}{l}\text { 95\% Confidence } \\
\text { Interval of the } \\
\text { Difference }\end{array}$} & & & \\
\hline & & & & Lower & Lower & & & \\
\hline $\begin{array}{l}\text { Apakah Pekerjaan } \\
\text { saudara saat ini - } \\
\text { Ter Dampak } \\
\text { Pandemi }\end{array}$ & $\begin{array}{l}2.5546 \\
2\end{array}$ & $\begin{array}{l}4.2560 \\
0\end{array}$ & .39015 & $\begin{array}{l}1.7820 \\
3\end{array}$ & $\begin{array}{l}3.3272 \\
2\end{array}$ & $\begin{array}{l}6.54 \\
8\end{array}$ & 118 & .000 \\
\hline
\end{tabular}

tersebut bahwa Jenis pekerjaan responden tidak berhubungan dengan Dampak Pandemi COVID-19.

Sumber: Data SPSS 2020

Berdasarkan pada Tabel.10 dapat dijelaskan bahwa Jenis Pekerjaan responden terhadap dampak Pandemi COVID-19 dapat dikatakan berdampak jika nilai $\mathrm{t}$ hitung $>\mathrm{t}$ tabel dan nilai Siq < alpha (0,005), dari Tabel diatas didapatkan bahwa nilai $\mathrm{t}$ hitung $(6,548)>\mathrm{t}$ tabel 1,980 dengan df 118 dan nilai Siq $0,000<0,005$ artinya bahwa semua Jenis Pekerjaan Responden sangat terdampak secara signifikan terhadap Pandemi COVID-19.

Pendapatan Responden sebelum COVID-19 dan Saat COVID-19.

Tabel.11 Analsis Corelation pendapatan responden sebelum Pandemi COVID-19 dan Pada Saat Pandemi COVID-19.

\begin{tabular}{lccccc}
\multicolumn{5}{c}{ Paired Samples Correlations } \\
\hline & & & $\mathrm{N}$ & Corelation & Siq. \\
\hline $\begin{array}{l}\text { Pendapatan } \\
\text { Pendapatan pada saat Pandemi }\end{array}$ & $\&$ & 119 & .690 & .000 \\
\hline Sumber: Data SPSS 2020 & & & &
\end{tabular}


Berdasarkan pada Tabel.11 Pendapatan responden sebelum Pandemi COVID-19 dan Pada Saat Pandemi
COVID-19 ada hubungan cukup signifikan terbukti dengan nila $\mathrm{r} 0,690$ dan Siq 0,000 < 0,005 dengan N 119.

Tabel.12. Analisis Uji t Dampak Pendapatan responden sebelum COVID-19 dan Pada Saat COVID-19.

Paired Samples Test

\begin{tabular}{|c|c|c|c|c|c|c|c|c|c|}
\hline & & \multicolumn{5}{|c|}{ Paired Differences } & \multirow{3}{*}{$\mathrm{t}$} & \multirow{3}{*}{ df } & \multirow{3}{*}{$\begin{array}{l}\text { Sig. } \\
(2- \\
\text { tailed })\end{array}$} \\
\hline & & \multirow[t]{2}{*}{ Mean } & \multirow[t]{2}{*}{$\begin{array}{c}\text { Std. } \\
\text { Deviation }\end{array}$} & \multirow[t]{2}{*}{$\begin{array}{l}\text { Std. } \\
\text { Error } \\
\text { Mean }\end{array}$} & \multicolumn{2}{|c|}{$\begin{array}{l}\text { 95\% Confidence } \\
\text { Interval of the } \\
\text { Difference }\end{array}$} & & & \\
\hline & & & & & Lower & Lower & & & \\
\hline $\begin{array}{l}\text { Pendapatan } \\
\text { Sebelum } \\
\text { Pandemi } \\
\text { Pendapatan } \\
\text { pada } \\
\text { Pandemi }\end{array}$ & saat & .28571 & .61262 & .05616 & .17450 & .39692 & 5.088 & 118 & .000 \\
\hline
\end{tabular}

Berdasarkan pada Tabel.12 (5,088) $>\mathrm{t}$ tabel 1,980 dengan df 118 dan dijelaskan bahwa Pendapatan responden nilai Siq $0,000<0,005$ artinya bahwa sebelum Pandemi COVID-19 dan Pada pendapatan responden sebelum Pandemi Saat Pandemi COVID-19 dapat COVID-19 dan sesudah Pandemi sangat dikatakan berdampak jika nilai $\mathrm{t}_{\text {hitung }}>\mathrm{t} \quad$ berdampak secara signifikan terhadap tabel dan nilai Siq < alpha $(0,005)$ dari Tabel diatas didapatkan bahwa $\mathrm{t}$ hitung pendapatan responden.

\section{Daya Beli Kebutuhan Pribadi dan Keluaraga Responden sebelum Pandemi COVID-19 dan Pada Saat Pandemi COVID-19.}

Tabel.13. Analsis Corelation Daya Beli Kebutuhan Pribadi dan Keluarga responden sebelum Pandemi COVID-19 dan Pada Saat Pandemi COVID-19.

Paired Samples Correlations

\begin{tabular}{lccc}
\hline & $\mathrm{N}$ & Corelation & Siq. \\
\hline $\begin{array}{l}\text { Daya Beli Kebutuhan Pribadi dan } \\
\text { Keluarga sebelum Pandemi \& Daya }\end{array}$ & 119 & & \\
$\begin{array}{l}\text { Beli Kebutuhan Pribadi dan Keluarga } \\
\text { pada saat Pandemi }\end{array}$ & & .667 & .000 \\
\hline
\end{tabular}

Berdasarkan pada Tabel.13 Daya Beli Kebutuhan Pribadi dan Keluarga responden sebelum Pandemi COVID-19 dan Pada Saat Pandemi COVID-19 didapatkan nila r 0,667 dan Siq 0,000 <
0,005 dengan N 119 artinya ada hubungan cukup signifikan antara Daya Beli Kebutuhan Pribadi dan Keluarga responden sebelum Pandemi COVID-19 dan Pada Saat Pandemi COVID-19 
Tabel.14. Analsis Uji t Daya Beli Kebutuhan Pribadi dan Keluarga responden sebelum Pandemi COVID-19 dan Pada Saat Pandemi COVID-19.

\begin{tabular}{|c|c|c|c|c|c|c|c|c|}
\hline \multicolumn{9}{|c|}{ Paired Samples Test } \\
\hline & \multicolumn{5}{|c|}{ Paired Differences } & \multirow{3}{*}{$\mathrm{t}$} & \multirow{3}{*}{ df } & \multirow{3}{*}{$\begin{array}{l}\text { Sig. } \\
(2- \\
\text { tailed })\end{array}$} \\
\hline & \multirow[t]{2}{*}{ Mean } & \multirow{2}{*}{$\begin{array}{l}\text { Std. } \\
\text { Deviati } \\
\text { on }\end{array}$} & \multirow[t]{2}{*}{$\begin{array}{l}\text { Std. } \\
\text { Error } \\
\text { Mean }\end{array}$} & \multicolumn{2}{|c|}{$\begin{array}{l}\text { 95\% Confidence } \\
\text { Interval of the } \\
\text { Difference }\end{array}$} & & & \\
\hline & & & & Lower & Lower & & & \\
\hline $\begin{array}{l}\text { Daya Beli } \\
\text { Kebutuhan Pribadi } \\
\text { dan Keluarga } \\
\text { sebelum Pandemi - } \\
\text { Daya Beli } \\
\text { Kebutuhan Pribadi } \\
\text { dan Keluarga saat } \\
\text { Pandemi } \\
\end{array}$ & $\begin{array}{l}.2773 \\
1\end{array}$ & .53559 & .04910 & .18009 & .37454 & $\begin{array}{l}5.64 \\
8\end{array}$ & 118 & .000 \\
\hline
\end{tabular}

Berdasarkan Tabel.14 dapat dijelaskan bahwa Daya Beli Kebutuhan Pribadi dan Keluarga responden sebelum Pandemi COVID-19 dan Pada Saat Pandemi COVID-19 dapat dikatakan berdampak jika nilai $\mathrm{t}$ hitung $>\mathrm{t}$ tabel dan nilai Siq < alpha $(0,005)$, dari Tabel diatas didapatkan bahwa nilai $\mathrm{t}$ hitung $(5,648)>\mathrm{t}$

\section{PEMBAHASAN}

\section{Jenis Pekerjaan}

Virus corona COVID-19 ini tidak hanya berdampak pada kesehatan. Tetapi juga pada beberapa sektor pekerjaan, pengkajian dampak ini mulai ringan hingga buruk akibat virus corona terhadap beberapa profesi di banyak wilayah. Apabila virus ini tidak segera mereda, perekonomian lokal dikhawatirkan akan bermasalah, akibat beberapa sektor dan profesi yang mengalami dampak virus corona, pekerjaan yang terdampak Pandemi COVID-19 yang umum diantaranya adalah sopir angkot, penghitungan ini berdasarkan skenario sedang yang dilakukan pemerintah tentang work from home, sekolah diliburkan, dan imbauan social distancing alias menjaga jarak, para sopir angkot menjadi korban dari dampak Pandemi COVID-19. Selain sopir angkot, pekerjaan tabel 1,980 dengan df 118 dan nilai Siq $0,000<0,005$ artinya bahwa Daya Beli Kebutuhan Pribadi dan Keluarga responden sebelum Pandemi COVID-19 sangat berdampak secara signifikan terhadap Daya Beli Kebutuhan Pribadi dan Keluarga responden pada saat Pandemi COVID-19.

yang paling terdampak virus corona COVID-19 adalah tukang ojek, baik tukang ojek konvensional maupun tukang ojek online. Sebab, aktivitas mayoritas instansi diliburkan, sehingga masyarakat banyak menghabiskan waktu di rumah. Akan tetapi berbeda dengan ojek konvensional, ojek online masih sedikit bisa beraktivitas karena bisa melayani pelayanan lain selain mengantarkan orang. Usaha Mikro Kecil dan Menengah atau UMKM juga terkena imbas dari merebaknya wabah corona COVID-19. Para pengusaha dan pemegang UMKM banyak yang melaporkan ke kementerian koperasi dan UKM. Tercatat lebih dari 21 koperasi dan UMKM melaporkan keluhannya tersebut. Ada lagi adalah pedagang. Karena imbauan social distancing, banyak pedagang bangkrut karena minim pembeli. Mall dan toko-toko sepi pengunjung. Karena kondisi pandemik corona, penurunan pendapatan pedagang 
menurun drastis. Jika wabah tidak segera mereda, para pedagang dikhawatirkan akan gulung tikar akibat sepinya pengunjung. Tidak Ketinggalan, Dewan perjalanan dan pariwisata dunia mencatat wabah virus corona COVID-19 ini mengancam lapangan kerja di sektor perjalanan dan juga pariwisata global, disaat perjalanan internasional tahun ini diperkirakan terpangkas hingga 25 persen. Sektor pariwisata lokal pun juga terkena imbasnya. Banyak bisnis pariwisata ditutup karena tempat wisata menjadi penularan terbesar virus corona. Sehingga banyak yang terancam merugi para pekerja di sektor wisata ini. Pekerjaan yang tidak ketinggalan adalah buruh. Sudah pasti perusahaan-perusahaan juga terancam tidak dapat memproduksi banyak karena virus ini. Pabrik-pabrik tutup karena para buruh tidak berani keluar rumah. (Latif, 2020)

Namun hal diatas berbeda dengan hasil penelitian yang didapatkan, dimana menurut hasil yang ada bahwa Jenis Pekerjaan responden yang tersebar mulai dari sektor pekerja pemerintahan, sektor BUMN dan perbankkan dan sektor pekerja yang lainnya dapat dijelaskan bahwa dari 119 responden Jenis Pekerjaan Responden terbanyak adalah Pekerjaan sektor pemerintah (ASN/TNI/ Polri/Guru/ Kesehatan/Pejabat Politik dll) dan Pekerja sektor Perbankkan atau BUMN sejumah 60 $(50,4 \%)$ responden.

Dari data hasil penelitian jika dilihat dari corelation atau hubungan, bahwa masing masing jenis pekerjaan responden tidak memiliki hubungan dengan Pandemi COVID-19 secara individu terbukti bahwa nilai corelation nya atau $r$ di anggka $-0,001$ dan nilai Sig 0,988 atau lebih besar dari nilai alpha 0,005 , namun secara menyeluruh dapat diartikan seluruh jenis pekerjaan diberbagai sektor merasakan atau terdampak Pandemi COVID-19 dengan sangat signifikan terbukti nilai tingkat terdampknya dapat di lihat dari nilai uji t nya bahwa $\mathrm{t}$ hitung $>\mathrm{t}$ tabel dan nilai sig < 0,005, dari hasil penelitian didapatkan bahwa $\mathrm{t}_{\text {hitung }}(6,548)>\mathrm{t}_{\text {tabel }}(1,980)$ dan nilai sig $0,000<0,005$.

Dengan demikian dalam penelitian ini menyatakan bahwa ternyata yang mengalami dampak atau yang terdampak Pandemi COVID-19 ini tidak hanya pada sektor pekerjaan yang rentan atau pekerjaan dengan kualitas yang buruk, tidak produktif dan pendapatannya rendah, tidak diakui dan dilindungi secara hukum, dan tidak memadainya perlindungan sosialnya. Namun ternyata sektor pekerjaan yang produktif dan dilindungi secara hukum juga ikut terdampak misalnya ASN, Polri, TNI dan pekerja sektor pemerintah lainnya juga sektor Perbankkan atau BUMN, meskipun jenis pekerjaannya termasuk berkualitas, produktif dan berpendapatan tetap tiap bulannnya. Bahkan perusahaan perkeretaapian dan BUMN juga tengah menghitung kerugian yang dialami perusahaan-perusahaan tersebut. Meskipun tetap beroperasi, perusahaan kereta api tetap dituntut untuk melayani masyarakat. Tetapi volume penumpang sudah pasti turun drastis dari hari normal. Masyarakat juga banyak yang memiliki ketakutan untuk menggunakan transportasi umum seperti kereta api, selain itu juga jumlah tiket yang menuju daerah-daerah rawan juga dibatasi. Sekaligus sebagai upaya menjalankan instruksi pemerintah untuk social distancing, akhirnya imbasnya juga pada pelaku pekerja di sektor tersebut. Termasuk juga pekerja di sektor penerbangan, dimana para pekerja di sektor penerbangan juga terkena imbas dari wabah corona COVID-19. Perkumpulan Angkatan Udara Internasional pernah menyampaikan bahwa perusahaan penerbangan yang beroperasi di Kawasan AsiaPasifik tahun ini akan mengalami kerugian sejumlah 27,8 milyar dollar akibat bencana virus corona ini.

Kita semua berharap Pandemi COVID-19 segera berakhir sehingga para pekerja dari semua sektor dapat memulai aktifitasnya dengan normal dan akhirnya dapat menghidupkan sendi-sendi perekonomian keluarga, masyarakat dan khususnya Perekonomian Indonesia menjadi lebih baik kedepan. 


\section{Pendapatan}

Daya beli berkaitan dengan tingkat konsumsi, harga dan pendapatan. Konsumen dengan daya beli rendah atau memiliki pendapatan yang relatif kecil, akan mengkonsumsi produk dengan harga yang relatif murah dengan jumlah yang relatif lebih sedikit agar dapat memenuhi kebutuhannya, dan jika memungkinkan bisa memenuhi seluruh kebutuhannya. Adapun faktor-faktor yang mempengaruhi daya beli masyarakat adalah sebagai berikut yaitu tingkat pendapatan dimana pendapatan merupakan suatu balas jasa dari seseorang atas tenaga atau pikiran yang telah disumbangkan, biasanya berupa upah atau gaji. Makin tinggi pendapatan seseorang makin tinggi pula daya belinya dan semakin beraneka ragam kebutuhan yang harus dipenuhi, dan sebaliknya.

Berdasarkan penelitian sektor pendapatan masyarakat di saat Pandemi COVID-19 dan sebelum Pandemi COVID19 sangat mengalami penurunan yang sangat signifikan terbukti bahwa pendapatan individu perbulan sebelum Pandemi COVID-19 jumlah terbanyak adalah pendapatan 1 juta s.d 5 juta sejumlah $65(54,6 \%)$ responden. Sedangkan pendapatan individu pada saat Pandemi COVID-19 jumlah terbanyak adalah pendapatan 1 juta s.d 5 juta sejumlah 88 $(73,9 \%)$ responden. Pada Analisis Uji-t dijelaskan bahwa Pendapatan responden sebelum Pandemi COVID-19 dan Pada Saat Pandemi COVID-19 dapat dikatakan berdampak jika nilai $t_{\text {hitung }}>\mathrm{t}_{\text {tabel }}$ dan nilai Siq < alpha $(0,005)$ dari Tabel diatas didapatkan bahwa $\mathrm{t}$ hitung $(5,088)>\mathrm{t}$ tabel 1,980 dengan df 118 dan nilai Siq $0,000<$ 0,005 artinya bahwa pendapatan responden sebelum Pandemi COVID-19 dan sesudah Pandemi sangat berdampak secara signifikan terhadap pendapatan responden.

Pergeseran pendapatan kearah minimal menjadi indikator bahwa Masyarakat di Jawa Tengah mengalami penurunan pendapatan yang signifikan karena disebabkan permasalahan yang ada, misalnya dampak dirumah saja, tidak berani keluar rumah untuk mencari pendapatan, disamping itu juga masalah pemutusan hubungan kerja (PHK) terhadap karyawan mengingat kekuatan perusahaan juga mulai menurun seiring dengan terjadinya pandemi saat ini. Perekonomian adalah hal yang sensitif sehingga apabila ada hal kecil yang berjalan tidak semestinya akan membuat pengaruh yang besar kepada perekonomian itu sendiri. Efek dari terbatasnya lapangan pekerjaan dan juga kesempatan bekerja karena dampak aturan yang diterapkan Pemerintah dalam Protokol pencegahan penularan COVID-19 menjadi menyebab tingginya angka pengangguran yang pada akhirnya mengurangi tingkat pendapatan juga kemakmuran. Semakin turunnya kesejahteraan masyarakat karena menganggur tentunya akan menurunkan keinginan seseorang dalam membeli barang. Berdasarkan penelitian Pendapatan responden sebelum Pandemi COVID-19 dan Pada Saat Pandemi COVID-19 sangat berdampak secara signifikan terhadap pendapatan masyarakat yang ada di Jawa Tengah.

\section{Daya Beli}

Daya beli (Purchasing Power) adalah kemampuan seseorang dalam mengkonsumsi suatu produk. Daya beli antara satu orang dengan orang yang lainnya pastilah berbeda. Hal tersebut dapat dilihat dari status orang tersebut, pekerjaan, penghasilan, dan sebagainya. Kemampuan daya beli digambarkan melalui pengeluaran per kapita riil. Daya beli juga mempunyai hubungan erat dengan suatu barang atau produk. Bila barang atau produk tersebut mempunyai harga yang murah, maka daya beli masyarakat terhadap barang tersebut juga akan meningkat. Hal ini berlaku seperti pada hukum permintaan. 
Permintaan adalah jumlah barang yang diminta pada suatu pasar tertentu dengan tingkat harga tertentu dan dalam periode waktu tertentu yang didukung oleh daya beli. Daya beli adalah kemampuan konsumen untuk membeli sejumlah barang yang diinginkan, yang biasanya dinyatakan dalam bentuk uang. Daya beli masyarakat ini ditandai dengan meningkat ataupun menurun, dimana daya beli meningkat jika lebih tinggi dibanding periode lalu sedangkan daya beli menurun ditandai dengan lebih rendahnya kemampuan beli masyarakat dari pada periode sebelumnya. Keterkaitan antara meningkat dan menurunnya daya beli dapat dilihat dari banyaknya permintaan masyarakat terhadap produk tertentu karena pengaruh harga dan pendapatan.

Institute for Development of Economics and Finance (Indef) menilai virus corona atau COVID-19 berdampak terhadap indikator ekonomi makro nasional baik jangka pendek dan panjang. Salah satunya daya beli masyarakat. Indikator yang terbesar menurun adalah indikator konsumsi rumah tangga. Terjadinya penurunan konsumsi rumah tangga ini mendorong pertumbuhan ekonomi juga turut menurun. Pertumbuhan yang menurun juga berdampak pada tingkat pembukaan lapangan kerja. Khususnya di zona merah corona yakni DKI Jakarta, Banten, Jawa Timur, dan Jawa Tengah. Selain itu, dampak COVID-19 juga menurunkan investasi secara nasional. Hal ini distimulus oleh produktivitas industri baik sektoral dan regional, yang menjadikan para investor yang semakin menahan investasinya. Kinerja industri yang bakal tergerus adalah industri peralatan listrik, asuransi, keuangan, dan perdagangan. Bahkan menurut Menteri Keuangan, Sri Mulyani, menjelaskan sesuai perkiraan analisis perhitungannya bahwa pertumbuhan ekonomi Indonesia bisa mencapai 2,5 persen bahkan sampai 0 persen jika pandemi virus corona atau COVID-19 masih akan berlangsung lebih dari 3 bulan terhitung setelah bulan Maret kedepan. (Santia,2020)

Hal ini selaras dengan hasil penelitian yang didapatkan bahwa Tingkat Daya Beli Kebutuhan masyarakat pada Individu dan Keluarga sebelum Pandemi COVID-19 terbanyak dengan kategori tingkat daya belinya Sedang sejumlah $59 \quad(49,6 \%)$ responden dan yang paling sedikit adalah kategori dengan tingkat daya beli rendah sejumlah $10(8,4 \%)$ responden. Namun Tingkat Daya Beli Kebutuhan masyarakat pada Individu dan Keluarga pada saat Pandemi COVID-19 terbanyak dengan kategori tingkat daya beli sedang sejumlah $64(53,8 \%)$ responden dimana ada peningkatan frekwensi dan yang paling sedikit Kategori dengan tingkat daya beli rendah sejumlah $24(20,2 \%)$ responden juga ada peningkatan frekwensi. Berdasarkan Analisa Uji-t bahwa Daya Beli Kebutuhan Pribadi dan Keluarga responden sebelum Pandemi COVID-19 dan Pada Saat Pandemi COVID-19 dapat dikatakan berdampak jika nilai $t_{\text {hitung }}>\mathrm{t}_{\text {tabel }}$ dan nilai Siq < alpha $(0,005)$, dari hasil didapatkan bahwa nilai $\mathrm{t}$ hitung $(5,648)>\mathrm{t}$ tabel 1,980 dengan df 118 dan nilai Siq 0,000 $<0,005$ artinya bahwa Daya Beli Kebutuhan Pribadi dan Keluarga responden sebelum Pandemi COVID-19 sangat berdampak secara signifikan terhadap Daya Beli Kebutuhan Pribadi dan Keluarga responden pada saat Pandemi COVID-19. Dari hasil ini dapat dijadikan acuan bahwa daya beli masyarakat untuk memenuhi kebutuhan individu sehari-hari saja mulai menurun bahkan sebelum Pandemi COVID-19 daya beli masyarakat meski pada kategori rendah namun dari frekwensi tiap kategori meningkat disaat pandemi COVID-19, dampak ini sangat dirasakan oleh Masyarakat di Jawa Tengah.

Ekonomi Indonesia saat ini sedang tidak baik-baik saja, terbukti dari menurunnya daya beli masyarakat. Isu ini menjadi sebuah topik yang hangat karena 
hal ini menjadi tulang punggung dalam perekonomian Indonesia. Apalagi Indonesia tidak bisa mengharapkan dari proses Export karena Pasar Global pun sedang lesu. Pada akhir tahun 2019, pertumbuhan ekonomi ada di angka 5,02 $\%$. Proyeksi perlambatan ini diperkuat dengan adanya peningkatan harga di barang, namun di barang lain harga malah menjadi stuck. Hal tersebut juga dibuktikan dengan menurunnya daya beli masyarakat Indonesia.

\section{KESIMPULAN}

Dari data hasil penelitian jika dilihat dari corelation atau hubungan, bahwa masing masing jenis pekerjaan responden tidak memiliki hubungan dengan Pandemi COVID-19 secara individu terbukti bahwa nilai Corelation nya atau $r$ di angka $-0,001$ dan nilai Sig 0,988 atau lebih besar dari nilai alpha 0,005 , namun secara menyeluruh dapat diartikan seluruh jenis pekerjaan diberbagai sektor merasakan atau terdampak Pandemi COVID-19 dengan sangat signifikan terbukti nilai tingkat terdampknya dapat di lihat dari nilai uji $t$ nya bahwa $t_{\text {hitung }}>\quad t_{\text {tabel }}$ dan nilai sig < 0,005, dari hasil penelitian didapatkan bahwa $\mathrm{t}$ hitung $(6,548)>\mathrm{t}$ tabel $(1,980)$ dan nilai sig $0,005<0,005$. Dengan demikian dalam penelitian ini menyatakan bahwa yang mengalami dampak atau yang terdampak Pandemi COVID-19 ini tidak hanya pada sektor pekerjaan yang rentan atau pekerjaan dengan kualitas yang buruk, tidak produktif dan pendapatannya rendah, tidak diakui dan dilindungi secara hukum, dan tidak memadainya perlindungan sosialnya. Namun ternyata sektor pekerjaan yang produktif dan dilindungi secara hukum juga ikut terdampak misalnya ASN, Polri, TNI dan pekerja sektor pemerintah lainnya juga sektor Perbankkan atau BUMN, meskipun jenis pekerjaannya termasuk berkualitas, produktif dan berpendapatan tetap tiap bulannnya.

Berdasarkan penelitian pada sektor pendapatan masyarakat di saat Pandemi COVID-19 dan sebelum Pandemi COVID19 sangat mengalami penurunan yang sangat signifikan terbukti bahwa pendapatan individu perbulan sebelum Pandemi COVID-19 jumlah terbanyak adalah pendapatan 1 juta s.d 5 juta sejumlah $65(54,6 \%)$ responden dan pada jumlah pendapatan individu per bulan di 50 juta keatas sejumlah $2(1,7 \%)$ responden. Sedangkan pendapatan individu pada saat Pandemi COVID-19 jumlah terbanyak adalah pendapatan 1 juta s.d 5 juta sejumlah $88(73,9 \%)$ responden dan pada jumlah pendapatan individu per bulan 21 juta s.d 50 juta sejumlah $1 \quad(0,8 \%)$ responden sehingga pendapatan di atas 50 juta sudah tidak ada pada saat pandemi COVID-19. Pada Analisis Uji-t d didapatkan bahwa $\mathrm{t}$ hitung $(5,088)>\mathrm{t}$ tabel 1,980 dengan df 118 dan nilai Siq $0,000<$ 0,005 artinya bahwa pendapatan responden sebelum Pandemi COVID-19 dan sesudah Pandemi sangat berdampak secara signifikan terhadap pendapatan responden. Pergeseran pendapatan kearah minimal menjadi indikator bahwa Masyarakat di Jawa Tengah mengalami penurunan pendapatan yang signifikan karena disebabkan permasalahan yang ada, misalnya dampak dirumah saja, tidak berani keluar rumah untuk mencari pendapatan, disamping itu juga masalah pemutusan hubungan kerja (PHK) terhadap karyawan mengingat kekuatan perusahaan juga mulai menurun seiring dengan terjadinya pandemi saat ini.

Hasil penelitian Tingkat Daya Beli Kebutuhan masyarakat pada Individu dan Keluarga sebelum Pandemi COVID-19 terbanyak dengan kategori tingkat daya belinya Sedang sejumlah $59 \quad(49,6 \%)$ responden dan yang paling sedikit adalah Kategori dengan tingkat daya beli rendah sejumlah $10(8,4 \%)$ responden. Namun Tingkat 
Daya Beli Kebutuhan masyarakat pada Individu dan Keluarga pada saat Pandemi COVID-19 terbanyak dengan kategori tingkat daya beli juga Sedang sejumlah $64(53,8 \%)$ responden dimana ada peningkatan frekwensi dan yang paling sedikit kategori dengan tingkat daya beli rendah sejumlah $24 \quad(20,2 \%)$ responden juga ada peningkatan frekwensi. Berdasarkan Analisa Uji-t didapatkan bahwa nilai $\mathrm{t}$ hitung $(5,648)>\mathrm{t}$ tabel 1,980 dengan df 118 dan nilai Siq $0,000<0,005$ artinya bahwa Daya Beli Kebutuhan Pribadi dan Keluarga responden sebelum Pandemi COVID-19 sangat berdampak secara signifikan terhadap Daya Beli Kebutuhan Pribadi dan Keluarga responden pada saat Pandemi COVID-19. Dari hasil ini dapat dijadikan acuan bahwa daya beli masyarakat untuk memenuhi kebutuhan individu sehari hari saja mulai menurun bahkan sebelum Pandemi COVID-19 daya beli masyarakat yang tinggi menurun menjadi sedang sampai ke rendah dan dampak ini sangat dirasakan oleh Masyarakat di Jawa Tengah.

\section{DAFTAR PUSTAKA}

Bayu (2020) "Dampak Virus Corona, S\&P Pangkas Proyeksi Pertumbuhan Ekonomi Tiongkok", 7 Februari 2020, https://katadata.co.id/ berita/2020/02/07/dampak-viruscorona-sp-pangkas-proyeksipertumbuhan-ekonomi-tiongkok, diakses 9 Mei 2020.

Fajriyah(2020) "Porak-poranda Ekonomi China Akibat Wabah Virus Corona, Banyak Usaha Terancam Bangkrut", 18 Februari 2020, https://www.merdeka.com/ uang/porak-poranda-ekonomichinaakibat-wabah-coronabanyak-usahaterancam-bangkrut. html, diakses 9 Mei 2020.

Iqbal Hasan. (2002). Pokok-pokok Materi Metodologi Penelitian dan Aplikasi. Jakarta: Ghalia Indonesia
Kneller, Richard, Michael Bleaney, and No rman Gemmell (1999). "Fiscal Policy and Growth:Evidence from OECD Countries". Journal of Public Econom ics

Kusuma (2020) "Daya beli Masyarakat Bisa Tambah Jeblok di April-Juni" 06 Mei 2020 , https://finance.detik.com/beritaekonomi-bisnis/d-5004646/duh-dayabeli-masyarakat-bisa-, diakses $18 \mathrm{Mei}$ 2020.

Latif (2020) " 8 Pekerjaaan yang terdampak virsu Corona COVID-19”, 26 Maret 2020,

https://www.dream.co.id/dinar/8pekerjaan-yang-terdampak-viruscorona-COVID-19 2003267.html , diakses 19 Mei 2020

Nursalam. (2011). Manajemen Keperawatan: Aplikasi Dalam Praktik Keperawatan Profesional. edisi 3. Jakarta: Salemba Medika.

Novika (2020) "Di Depan DPR, Mentan Ngeluh Ekspor-Impor Pangan Terganggu Corona", 17 Februari 2020,

https://finance.detik.com/beritaekono mi-bisnis/d-4902563/ di-depan-dprmentan-ngeluhekspor-impor-panganterganggucorona, diakses 11 Mei 2020.

Rina (2020) "Update, 1,4 Juta Pekerja Dirumahkan \& PHK , Jakarta Terbanyak", 09 April 2020, https://www.cnbcindonesia.com/news /20200409201441-4-151017/update14-juta-pekerja-dirumahkanphkjakarta-terbanyak, diakses $18 \mathrm{Mei}$ 2020.

Santia (2020) "Virus Corona Terjadi 6 Bulan, Daya Beli Masyarakat Terpukul Paling Berat", 24 Maret 2020, https://www.merdeka.com/uang/viruscorona-terjadi-6-bulan-daya-beli- 
masyarakat-terpukul-paling-berat.html , diakses 19 Mei 2020

Tobing (2020) "Virus Corona Tekan Ekonomi Tiongkok, Dunia Waspadai Perlambatan Global", 5 Februari 2020, https://katadata.co.id/ telaah/2020/02/05/virus-coronatekanekonomi-tiongkok-duniawaspadai- perlambatan-global, diakses 9 Mei 2020.

Yose, Fajar (2020) "Mengukur Dampak COVID-19 pada Pertumbuhan Ekonomi dan Perdagangan Indonesia 2020" 26 Maret 2020. CSIS Commentaries DMRU-015, Indonesia. 